\title{
Radiologist in the picture for top job at NIH
}

Erika Check, Washington

Elias Zerhouni, a radiologist and senior administrator at the Johns Hopkins University School of Medicine in Baltimore, Maryland, is set to be nominated by President George Bush as director of the National Institutes of Health (NIH).

If his nomination goes ahead this week, as government and university officials anticipate, and is confirmed by the Senate, Zerhouni will fill a position that has been vacant since December 1999, when Harold Varmus departed to become president of the Memorial Sloan-Kettering Cancer Center in New York.

Varmus is a Nobel prizewinning molecular biologist, and Zerhouni has never worked in basic research. But supporters say that the 50-year-old Algerian would bring his own mix of relevant skills to the administration of the world's largest research agency.

Zerhouni, a naturalized American citizen who is married with three children and lives in Pasadena, Maryland, earned his medical degree from the University of Algiers before coming to Hopkins as a resident in 1975 . He helped to pioneer the use of new techniques in clinical radiology at the medical school

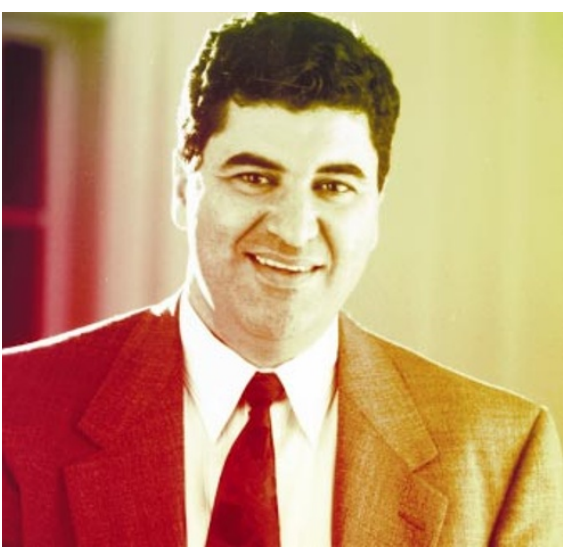

Elias Zerhouni is seen by supporters as an innovator with an administrative track record.

and worked in several administrative positions there. He also founded a company that sells devices for use in high-resolution magnetic resonance imaging of the body.

Colleagues say that Zerhouni has a warm, engaging personality, adding that he is seen as an innovator who devised techniques such as tagged magnetic resonance imaging, a noninvasive way to monitor heart contractions.

\section{Ecologists seek sustainable future}

Rex Dalton

An international group of researchers is preparing an agenda on 'sustainable science' for discussion at the World Summit on Sustainable Development, to be held this summer in Johannesburg.

The initiative is led by the International Council for Science (ICSU) in Paris and the Third World Academy of Sciences in Trieste, Italy, and is coordinated by William Clark, an ecologist at Harvard University.

ICSU, the main international federation of scientific societies, was asked by the United Nations to suggest ways of involving science and technology in the summit, which will run from 26 August to 4 September. But there is scepticism about the summit's ability to reach any meaningful conclusions about how science and technology can be applied in poorer countries. Privately, one official involved opines that it will struggle to achieve anything beyond "people in suits sitting around a table discussing options".

But Jane Lubchenco, president-elect of ICSU and an ecologist at Oregon State University, is supporting the effort."We have to think differently on how to make the transition to sustainability," she says.

Pamela Matson, an ecologist at Stanford University in California, says that science must become more engaged in addressing the
John Griffin, chair of neurology at the medical school, says that Zerhouni was an administrator with "vision" who also made decisions fairly, based on the data and faculty input. Scientists at Hopkins say that Zerhouni, as executive vice-dean of the medical school, has paid close attention to their needs.

Zerhouni's experience at Hopkins, his supporters argue, would stand him in good stead for the administrative challenges of running the NIH. "The NIH is just a bigger version of Johns Hopkins," says Hopkins neuroscientist Jeffrey Rothstein. "Hopkins and the NIH are each institutions that believe strongly in 'bench to bedside' — which means you do the basic research and are surrounded by colleagues who do the clinical research."

There is little public record of Zerhouni's political views, but he was a consultant to Ronald Reagan's White House from 1985 to 1988 where, some observers speculate, he may have made the connections that could lead to his nomination.

More recently, Zerhouni has been involved in the planning of a new \$80-million Institute for Cell Engineering at Hopkins, which will conduct interdisciplinary research on stem cells when it opens next year. But Griffin, who has also been involved in planning the institute, cautions that Zerhouni's involvement there doesn't signal an endorsement of experiments on human embryonic stem cells.

However, another researcher familiar with the institute, who didn't want to be identified, says that there is a "bit of a disconnect" between Zerhouni's support for the institute and the Bush administration's plans to restrict embryonic stem-cell research and ban therapeutic cloning.

If he does become director of the $\mathrm{NIH}$, Zerhouni will have plenty to keep him occupied besides the politics of regenerative biology. The agency's budget is on course to double from $\$ 13.6$ billion in 1998 to $\$ 27$ billion in 2003. But since Varmus's departure, many institute directors have left. Some researchers characterize the agency as lacking strategic direction, and being embroiled in infighting over efforts by Tommy Thompson, the health secretary, to centralize control of its work (see Nature 415, 250; 2002).

It would be down to Zerhouni - an unknown quantity to most NIH staff and grantees - to restore the agency's coherence and morale. Supporters say that he has the background to do the job. "Medicine is being driven by a technological explosion," says Reed Dunnick of the University of Michigan in Ann Arbor, president-elect of a radiologists' group, the American Roentgen Ray Society. "Someone with his understanding of technology is exactly right for the NIH." 